\title{
UTILITARIAN ATTRACTIVENESS OF AGRICULTURAL PLOTS - CASE STUDIES OF A COMPLEX OF PLOTS LOCATED IN THE SZCZEPANKOWO VILLAGE (WARMIA AND MASURIA REGION)
}

\author{
Robert Muszyński, Katarzyna Kocur-Bera
}

\begin{abstract}
Summary
The attractiveness of agricultural real estate is affected by a number of factors, of which the most important include: location, convenience of access, utilitarian value, spatial configuration, neighbourhood, agricultural culture, and level of crop difficulty. The attractiveness is related to spatial order. Indicators for the assessment of spatial order can be also used to assess the utilitarian attractiveness. The scope of features also depends on the buyers, i.e. potential users of the land. The aim of the present research was to assess the utilitarian attractiveness of agricultural parcels. The selection of indicators was made on the basis of a literature review and indications from the surveys. The research object was a complex of plots of the village of Szczepankowo located in the Lubawa municipality (Warmia-Masuria region). Each studied plot used for agriculture was assessed in terms of twelve attributes representing spatial order. The results of the assessment are presented in tabular and graphical format. The vast number of plots in the studied complex has favourable attractiveness for agricultural use. Due to the diverse nature of the elements and forms occurring in rural areas, ensuring spatial order in these areas is difficult. The use of the developed indicators provides the opportunity to indicate which of the attributes of the assessed space may have a negative impact on the attractiveness. Indication of elements disturbing spatial order and introducing chaos in space enables carrying out corrective actions, for example, agricultural land management measures that make it possible to influence the spatial structure of agricultural plots.
\end{abstract}

\section{Keywords}

spatial order • rural areas $\bullet$ utilitarian attractiveness of agricultural plots

\section{Introduction}

Dynamic economic development in the second half of the twentieth century contributed to the improvement of living conditions in many developed countries (Western Europe, North America), but the side effect was accelerated use of nature [Żylicz 2004]. In the 1970 s, the main consideration was the problem of diminishing natural resources 
in the perspective of demographic and economic growth [Żmija 2014]. The solution to this problem is the concept of sustainable development [Stanny and Czarniecki 2011]. At the Rio de Janerio Summit sustainable development was recognized as a strategy for recognizing and solving contemporary economic, social and environmental problems [Goodland 1995].

In Poland, agriculture is the basic sector of the economy in rural areas, which significantly affects the shaping of the spatial structure. The agricultural landscape, shaped for many years, covers over $60 \%$ of the country [Bański et al. 2008]. The impact of agriculture on the environment is related to the intensity of production and the level of adjustment to local socio-economic and natural conditions. Through excessive interference in the landscape, conflicts arise. These conflicts concern the philosophy of land use. Naturally valuable areas focus and bring together different social requirements [Balloon 2011]. Therefore, it is necessary to use the rural areas in such a way that agriculture can co-exist with nature, shaping the "semi-natural" landscape.

Agriculture is aimed at satisfying the country's alimentary needs, while not reducing the natural values of the environment. Spatial order is of great importance in maintaining this balance. Already in ancient times, there was a need to "order" the surroundings and organization of life. The existence of harmony has become a necessity for proper functioning and development. Order is a well-arranged whole in many areas of human activity. People live and develop in a space that in some way limits them through its natural and anthropogenic features. Taking into account these limitations, all activities aimed at spatial development should meet the requirements of spatial order so that various elements of space are harmoniously connected. The legal wording referring to the need of taking spatial order into account appears in the Act of 07 July 1994 on spatial development. The problem is only signalled there, without providing a more precise definition. A more detailed definition of spatial order appears only in the Act of 27 March 2003 on spatial planning and development [Cymerman and Podciborski 2004].

Poland is a dynamically developing country. In recent decades, Polish countryside has experienced intense social, cultural and economic changes [Sadura 2017]. Fast development strongly affects spatial development. Nowadays, one can notice many monoculture crops, architectural chaos, and dispersed buildings in rural areas. According to Znaniecki [1971] and Jałowiecki [2003], chaos occurs when there is a deviation from a certain norm, caused by the presence of objects that should not be located in a given place. Numerous studies and analyses show that suburbanization is one of the main causes of spatial chaos [Bourne 2001, Filion 2000, 2003, GutryKorycka 2005, Lisowski 2004, 2005, Parysek 2008 et al.]. A characteristic feature of suburbanisation is the expansion of cities as a result of rapid development of peripheral areas and suburban zones. The result is occupying land previously used for agriculture, now taken over by built development [Parysek 2008]. In Poland, the expansion of cities to rural areas is progressing dynamically, characterized by high consumption of space and lack of spatial order [Litwińska 2008]. Lack of order is often identified with spatial chaos [Jałowiecki 2003]. Both spatial chaos and spatial order are difficult to define 
precisely, let alone to measure. Both these concepts have an aesthetic aspect, as well as a functional aspect, which overlap each other [Wdowicka 2012].

In the national, regional and local area, the spatial order is one of the main objectives of the spatial development plans and the development strategy of respective administrative units. Spatial order indicates the way of proper and harmonious shaping of spatial, taking into account social, environmental, cultural and economic needs. It consists in designing the distribution of economic functions in such a way as to ensure their optimal use and their peaceful coexistence adjacent to each other. In rural areas, an important aspect is the structure of agricultural land, and agrarian structure, which are responsible for the aesthetic values of the landscape. Spatial order is therefore necessary for sustainable development [Bański J. et al., 2008].

When analysing the definitions of spatial order proposed by Dembowska [1978], Domański [1989], Malisza [1984], Paryska [2006] and Wysocka and Witkowska [2004], it can be demonstrated that there are many ways of portraying development and spatial order. Interpretations can be made at various angles and in various aspects - for instance, legal, social goals and public utility, sustainable development, space management, or spatial planning. There is therefore a high risk of a wide spectrum of spatial phenomena and processes affecting spatial order. However, one should strive for selective and synthetic choice of spatial development indicators [Borys 2005]. The research used the method described by Cymerman [2011], which aims to determine the spatial order of plots used for agriculture. The analysis uses appropriate measures that facilitate determining which elements of the plot negatively affect, and which positively influence the spatial order. The Cymerman method was enriched with a review of literature and an analysis of questionnaire surveys. They made it possible to identify features that, according to the respondents, affect spatial order and functionality of use.

The main objective of the present research was the analysis of spatial order and attractiveness, discussed for a selected complex of plots. In order to achieve the objective, it was necessary to develop indicators of the spatial order for rural areas, measures for the assessment of individual spatial order indicators, as well as procedures and assessment principles for individual indicators. The analysis of literature and the results of surveys conducted among the farmers' community in the residents living in the studied location were used in order to determine the factors shaping the spatial order. Respondents indicated features that they thought affected spatial order and the usability of plots. Indicators of spatial order and utilitarian attractiveness of land overlap. Features that affect the usability of plots are largely shaped by the preferences of potential users.

\section{Materials and methods}

A fragment of agricultural production space was selected for the research, which is a complex of plots located in Szczepankowo, in the south-western part of the WarmiaMasuria region, in the Iława district, Lubawa municipality. The analysed area is characterized by not particularly fertile soils. The municipality has one of the largest shares of 
arable lands (almost 80\%) in the region. Arable land accounts for about $66 \%$ of the total area, while the share of grassland is at a very low level (around 12\%). Forests and tree stands also constitute a small percentage of the area - around 13\%. Szczepankowo has the character of a dispersed village, with mostly small and medium-sized farms. The area of the village is characterized by hilly terrain and low forest cover. Figure 1 shows the approximate location of the analysed area.

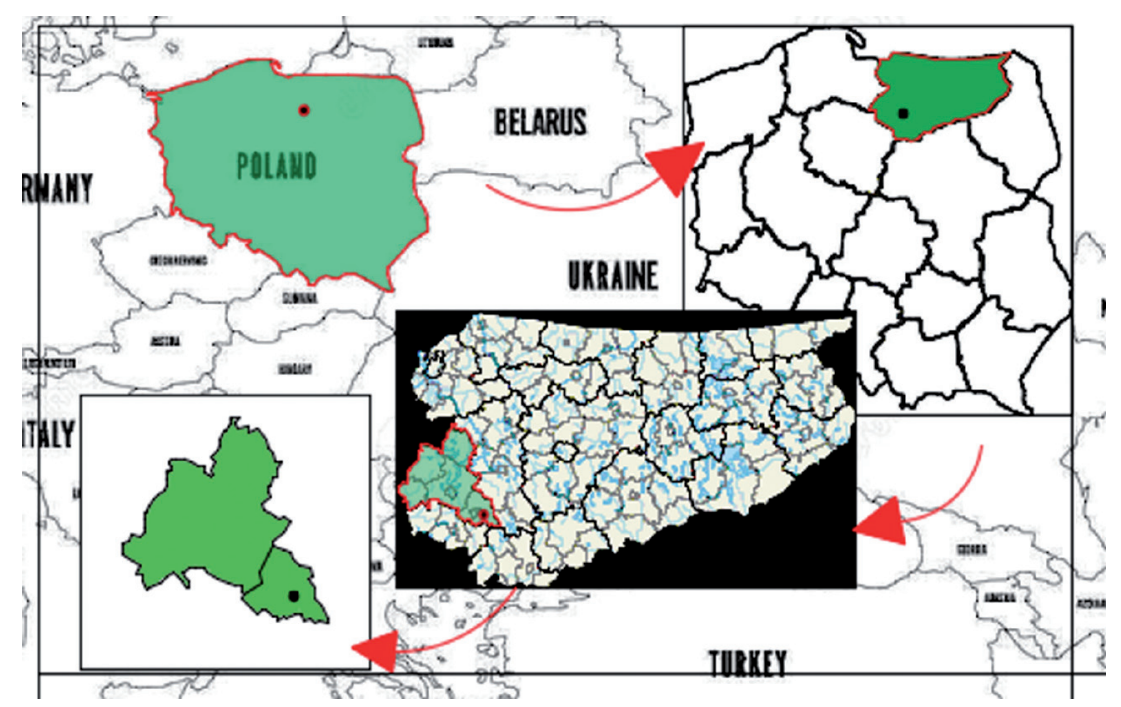

Source: Authors' own study

Fig. 1. Location of the studied area

Elements of space are characterized by a number of individual features. Each of the existing objects has a greater or lesser impact on spatial order. Indicators and elements affecting spatial order were selected on the basis of an analysis of subject literature. A few of the indicators were distinguished, most frequently appearing in the subject literature, which served to investigate the spatial order in the studied area [Harasimowicz et al. 2009, Hełdak 2010, Podciborski and Trystuła 2010, Podciborski and Kil 2011, Zarzycki 2011, Płaza et al. 2014, Śleszyński 2015]. These include, among other things: (1) the shape of the plot boundary; (2) fitting the plot into spatial invariants (for instance, forest, river, paved road, etc.); (3) straightness of artificial (land record) boundaries separating the neighbouring plots; (4) location of the plot in relation to the directions of the world (photophysiological needs of plants); (5) transportation accessibility of the plot; (6) linear internal disharmony of the plot; (7) spatial harmony of land ownership; (8) spatial harmony of use; and (9) uniformity of use (use homogeneity) of the interior of the plot.

In addition, the respondents indicated that the following should be taken into account in analysing the utilitarian attractiveness of land: (10) quality of arable land 
(bonitation class); (11) distance from areas of compact housing (densely built-up); and (12) the surface size of the plot.

When assessing the shape of the plot boundary (1), the following factors were taken into account: surface size, parallelism of the sides of the plot, and its geometric shape. This assessment takes into account that along with the increase of the plot area, the criterion for assessing the correctness of shape should be less stringent. The larger the plot area and the more regular (close to the quadrilateral) shape, the better the spatial order of the plot. The assessment of fitting the plot into spatial invariants (2) was made by determining what percentage of the plot's boundaries coincides with natural boundaries, such as for example, roads, ditches, slopes, forests, etc. The larger the percentage of the fit, the higher the score of this particular measure. While defining the straightness of artificial boundaries (i.e. land record boundaries) (3) that separate the neighbouring plots, the number of plot boundary bends/breaks was taken into account (it was assumed that 4 bends/breaks produce the optimal plot shape in terms of utility). The measure for assessing the suitability of plot limits and exposure to the physiological needs of plants (4) was divided into four categories. The most favourable exposure is the north-south direction of the longer plot boundary. The assessment of the other types of exposure was related to the optimal one.

In the agricultural production, the transportation accessibility of plots plays an important part (5). The accessibility has been taken into account by adopting road density ratio per area unit. According to studies by Jasiński and Nowak [1985], the most favourable road density is $35 \mathrm{~m} / \mathrm{h}$. The more the result in the studied area deviates from the ideal density, the less favourable this particular measure. The assessment of the internal disharmony of the plot (6) depends on the percentage share of the size of linear elements to the total plot area size. Line elements such as ditches and watercourses constitute natural obstacles in the use of the plot. The greater the percentage of linear obstacles, the less favourable the spatial order.

Spatial harmony (7) depends on how the parcels adjacent to the area are used. The greater the disproportion between the surface areas of the surrounding plots (and their number), the more flawed the spatial order and its perception. The analysis of subject literature showed that the best measure of the assessment is the percentage share of the length of the borders. The assessment of spatial harmony of use (8) is based on the interaction of specific functional uses, and it has been described as either beneficial (favourable) or unfavourable. Use homogeneity (uniformity) of the interior of the plot (9) is determined on the basis of the size of the plot and the number of ecological contours within the plot. The higher the number of ecological contours within the plot, the lower the rating is. According to this approach, along with the increase in the plot area, the impact of the number of ecological contours on spatial order is less critical.

Field intelligence and a survey conducted with the local farmers' community (potential users of plots in the surveyed area), confirmed that the spatial order indicators designated on the basis of the literature analysis are correct, and allowed to complete the list by adding the distance of the habitat plot from compact housing (10), the total area of the plot (11) and the quality of the soil (bonitation class) (12). The distance 
from dense housing was determined in meters from compact village buildings, along access roads. The further the distance of the plot from compact housing, the lower the score for this measure. The most attractive plots are those located closest to the inhabited plots, due to travel time and costs [Gniadek 2012, Radziszewska and Jaroszewicz 2012]. According to Woch [2012], plots with a small area size are hardly profitable in terms of utilitarian attractiveness.

Each of the features discussed was assigned indicators, according to which the plot was assessed. All features were translated to the scale of $0-3$, in order to show one indicator for each plot. All features were considered equal in importance, because the Cymerman method, which is applied here, does not envisage the weighing of features. Each of the examined areas is considered individually, all the indicators are important in the analysis, and furthermore, it is difficult to indicate the feature that affects the spatial order in the studied area most. The final result is divided into classes of utilitarian attractiveness. Detailed principles for assigning points to individual indicators are presented in Appendix 1.

The proposed measures for the assessment of spatial order can be used to assess objects of varying spatial scale, because the basic field in each case is the cadastral land plot.

For the present study, maps of land and building records were used, as well as orthophotomaps showing the current land use, which are available at www.atlas.warmia. mazury.pl and https://powiatolsztynski.geoportal2.pl/.

\section{Results and discussion}

Table 1 presents the results of the spatial order assessment for the plots complex (30). Comparative research was carried out in two stages. First, the attributes most frequently indicated in the literature of the subject were evaluated, and then they were supplemented with the attributes indicated by the respondents of the survey. The final score indicated the impact of additional features on the level of the utilitarian attractiveness index for particular of plots.

Table 1. Assessment of spatial order attributes

\begin{tabular}{|c|c|c|c|c|c|c|c|c|c|c|c|c|c|c|c|}
\hline \multirow{2}{*}{$\begin{array}{l}\text { Plot } \\
\text { No. }\end{array}$} & \multirow{2}{*}{$\begin{array}{l}\text { Area } \\
{[\text { ha] }}\end{array}$} & \multicolumn{9}{|c|}{ Attribute } & \multirow{2}{*}{$\begin{array}{c}\text { Total } \\
(1)-(9)\end{array}$} & \multicolumn{3}{|c|}{ Attribute } & \multirow{2}{*}{$\begin{array}{l}\text { Total } \\
\text { (1)-(12) }\end{array}$} \\
\hline & & (1) & (2) & (3) & (4) & (5) & (6) & (7) & (8) & (9) & & (10) & (11) & (12) & \\
\hline 198 & 0.07 & 1.5 & 1 & 3 & 1 & 2 & 3 & 0 & 2 & 3 & 16.50 & 3 & 0 & 0 & 19.50 \\
\hline 199 & 0.19 & 1.5 & 1 & 3 & 1 & 2 & 3 & 0 & 2 & 3 & 16.50 & 3 & 0 & 0 & 19.50 \\
\hline 200 & 0.25 & 3 & 0 & 3 & 1 & 2 & 3 & 0 & 2 & 3 & 17.00 & 3 & 0 & 3 & 23.00 \\
\hline 217 & 6.13 & 0 & 1 & 1 & 1 & 3 & 2 & 1 & 0 & 1.8 & 10.80 & 2.3 & 3 & 2 & 18.05 \\
\hline 218 & 2.77 & 1.5 & 1 & 3 & 1 & 3 & 3 & 2 & 0 & 1.8 & 16.30 & 2.3 & 2.3 & 2 & 22.80 \\
\hline
\end{tabular}




\begin{tabular}{|c|c|c|c|c|c|c|c|c|c|c|c|c|c|c|c|}
\hline 219 & 3.89 & 1.5 & 1 & 3 & 2 & 3 & 1 & 3 & 0 & 1.8 & 16.30 & 2.3 & 2.3 & 3 & 23.80 \\
\hline 220 & 4.66 & 1.5 & 1 & 3 & 2 & 3 & 0 & 3 & 3 & 2.4 & 18.90 & 2.3 & 2.3 & 2 & 25.40 \\
\hline 222 & 3.91 & 3 & 1 & 3 & 1 & 2 & 3 & 1 & 3 & 1.8 & 18.80 & 0.8 & 2.3 & 3 & 24.80 \\
\hline 223 & 1.94 & 1.5 & 1 & 2 & 1 & 3 & 3 & 2 & 0 & 1.2 & 14.70 & 1.5 & 1.5 & 3 & 20.70 \\
\hline 224 & 6.79 & 3 & 0 & 3 & 2 & 2 & 2 & 3 & 0 & 1.8 & 16.80 & 1.5 & 3 & 3 & 24.30 \\
\hline 225 & 6.27 & 3 & 1 & 2 & 2 & 3 & 2 & 3 & 3 & 2.4 & 21.40 & 1.5 & 3 & 2 & 27.90 \\
\hline 227 & 3.05 & 3 & 0 & 3 & 2 & 2 & 3 & 3 & 0 & 1.8 & 17.80 & 1.5 & 2.3 & 2 & 23.55 \\
\hline 230 & 5.20 & 3 & 0 & 2 & 2 & 2 & 3 & 2 & 3 & 2.4 & 19.40 & 1.5 & 3 & 2 & 25.90 \\
\hline 233 & 3.00 & 1.5 & 0 & 2 & 2 & 2 & 3 & 2 & 0 & 1.8 & 14.30 & 1.5 & 2.3 & 3 & 21.05 \\
\hline 236 & 4.29 & 3 & 1 & 3 & 1 & 3 & 3 & 3 & 3 & 2.4 & 22.40 & 0.8 & 2.3 & 3 & 28.40 \\
\hline 237 & 4.52 & 3 & 1 & 3 & 1 & 3 & 3 & 3 & 3 & 2.4 & 22.40 & 0.8 & 2.3 & 3 & 28.40 \\
\hline 238 & 6.19 & 3 & 0 & 2 & 2 & 2 & 3 & 3 & 3 & 2.4 & 20.40 & 0.8 & 3 & 1 & 25.15 \\
\hline $14 / 2$ & 3.33 & 1.5 & 0 & 3 & 1 & 2 & 3 & 2 & 3 & 2.4 & 17.90 & 0.8 & 2.3 & 3 & 23.90 \\
\hline $14 / 3$ & 4.07 & 1.5 & 0 & 1 & 1 & 2 & 3 & 2 & 3 & 3 & 16.50 & 0.8 & 2.3 & 3 & 22.50 \\
\hline $229 / 2$ & 2.00 & 3 & 0 & 3 & 2 & 2 & 3 & 2 & 0 & 1.2 & 16.20 & 1.5 & 1.5 & 1 & 20.20 \\
\hline $229 / 3$ & 1.51 & 0 & 0 & 1 & 2 & 1 & 3 & 0 & 0 & 1.2 & 8.20 & 1.5 & 1.5 & 2 & 13.20 \\
\hline $229 / 4$ & 3.39 & 1.5 & 0 & 3 & 2 & 2 & 3 & 2 & 0 & 1.2 & 14.70 & 1.5 & 2.3 & 2 & 20.45 \\
\hline $231 / 2$ & 4.80 & 1.5 & 0 & 2 & 2 & 2 & 1 & 2 & 1 & 1.8 & 13.30 & 0.8 & 2.3 & 3 & 19.30 \\
\hline $231 / 4$ & 1.52 & 3 & 0 & 3 & 2 & 2 & 3 & 2 & 3 & 3 & 21.00 & 1.5 & 1.5 & 1 & 25.00 \\
\hline $231 / 5$ & 0.50 & 3 & 1 & 3 & 1 & 3 & 3 & 0 & 0 & 0.6 & 14.60 & 1.5 & 0.8 & 2 & 18.85 \\
\hline $232 / 1$ & 7.84 & 0 & 0 & 0 & 2 & 2 & 2 & 1 & 3 & 2.4 & 12.40 & 1.5 & 3 & 1 & 18.90 \\
\hline $232 / 2$ & 0.30 & 3 & 1 & 3 & 2 & 3 & 3 & 0 & 0 & 0.6 & 15.60 & 1.5 & 0.8 & 2 & 19.85 \\
\hline $234 / 1$ & 14.95 & 0 & 2 & 1 & 1 & 3 & 3 & 1 & 3 & 3 & 17.00 & 0.8 & 2.3 & 3 & 23.00 \\
\hline $239 / 3$ & 1.46 & 1.5 & 0 & 2 & 2 & 1 & 3 & 2 & 0 & 1.8 & 13.30 & 0.8 & 1.5 & 1 & 16.55 \\
\hline $239 / 4$ & 0.95 & 1.5 & 0 & 3 & 2 & 2 & 3 & 1 & 3 & 3 & 18.50 & 0.8 & 0.8 & 2 & 22.00 \\
\hline
\end{tabular}

Source: Authors' own study

Table 1 shows that, on average, every plot in the examined complex received 22.20 points, which means that they were in the middle class of utilitarian attractiveness of plots for agricultural use. When analysing the assessment of the shape of the plot boundary (1) in the studied area, most plots have the shape of a quadrangle or a regu- 
lar polygon. The lowest rated, in terms of this feature, were plots $217,229 / 3,232 / 1$ and 234/1, which are characterized by many border bends/breaks. In the complex of plots, fitting into spatial invariants (2) is low. The vast majority of boundaries are artificially designated, and their straightness is preserved. One exception is plot 232/1. Taking into account the physiological needs of plants (4), almost $60 \%$ of the plots have the correct shape in relation to the exposure/cardinal directions. Transportation accessibility (5) in the analysed area is moderate, which means that there are neither too few nor too many roads. Internal disharmony (6) significantly hinders cultivation only on plot 220. Plots $231 / 5$ and $232 / 2$ are characterized by a lack of homogeneity in the use of interior of the plot (9). For the attributes $(10,11,12)$, which the respondents indicated, the best scores were given to plots 217, 219 and 224. The lowest scores were given to plots 198 and 199.

Considering the results individually (Fig. 2), the lowest attractiveness is recorded for plot $229 / 3$ - both when we examine it according to 9 attributes, and to 12 . In the same class there are also plots $239 / 3$ and 217. Plot number 239/3, just like plot number $229 / 3$, has a small area. Despite its fairly good shape and surface size, plot 217 , was classified to the weakest category due to its unattractive neighbourhood, unfavourable exposure (location in relation to the directions of the world), and low harmony of use. The best results were obtained for plots 236 and 237. They both have a favourable shape (that of a quadrangle). Both the harmonious, homogenous land use within the plots and in the surrounding of the plots, as well as the orientation of the borders, the surface sizes, and the distance from the compact village building, make them attractive for agricultural use.

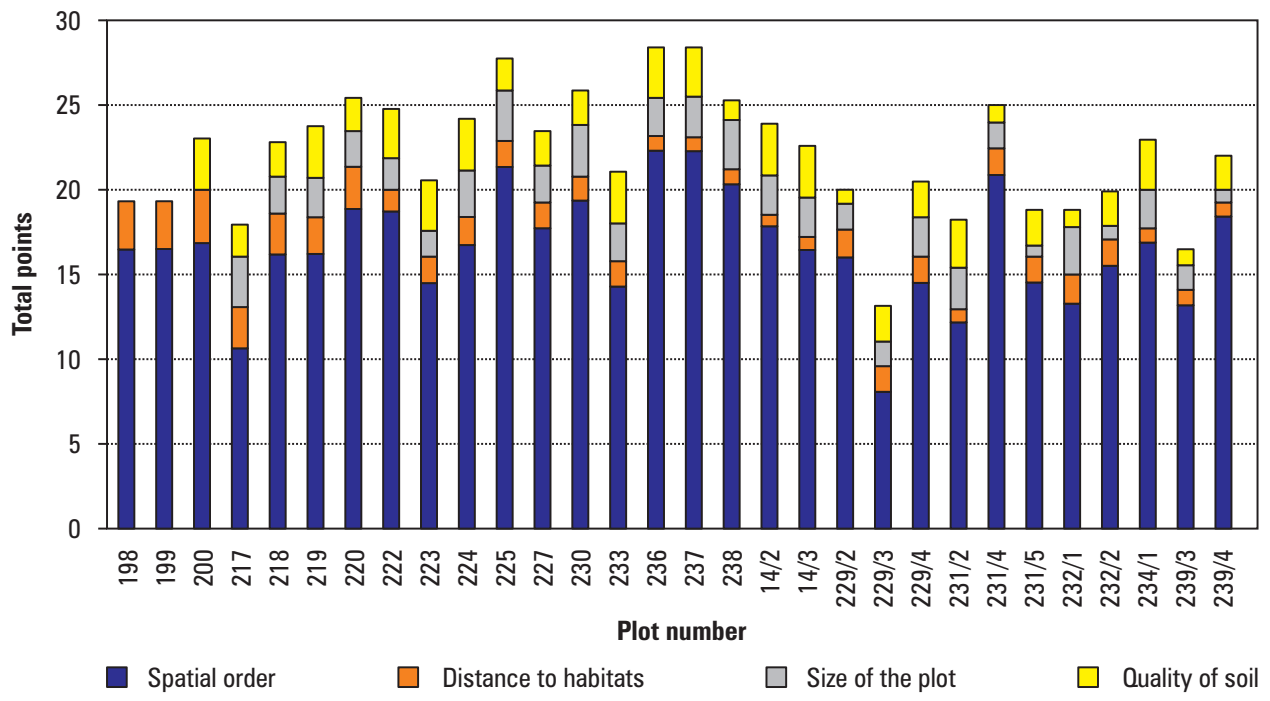

Source: Authors' own study

Fig. 2. Utilitarian attractiveness of particular plots in the complex, based on 9 and 12 attributes 
The plots with the highest attractiveness, assessed on the basis of traits resulting from the analysis of subject literature, remained the most attractive after taking into account the additional features indicated by the respondents in the survey. Some of the plots gained on the scale of attractiveness, and the highest increase in the attractiveness rating occurred in plots 217, 219 and 224. The lowest scores in relation to features 10-12 were given to plots 198 and 199 (Fig. 3). After these features were taken into account, the imperfections of these plots were revealed that could not have been determined earlier (based only on features 1-9). These are poor quality soils, and very small area sizes of plots, which hinder cultivation.

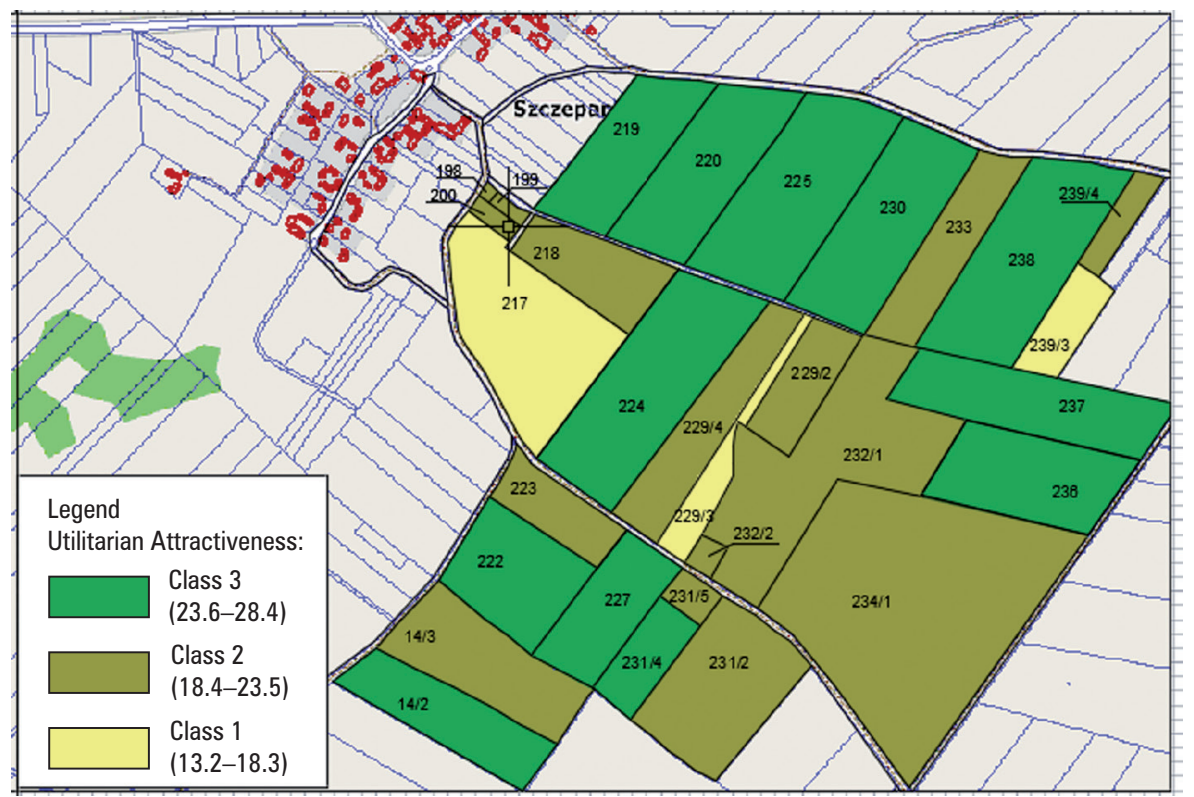

Source: Authors' own study

Fig. 3. Utilitarian attractiveness map of the complex of plots

\section{Conclusions}

The analysis of subject literature enabled the selection of indicators and the assessment of the spatial order for the given complex of plots. When analysing the results, it has been established that plots with regular shape and similar surface size were assigned a higher class of spatial order. In the lowest class of spatial order, there are plots of irregular shape and the area size deviating from that of the others. Indicator (9) - the uniformity or homogeneity of use in the interior of the plot - had a large impact on the diversity of spatial order in the examined complex. In the studied complex, the best rank of spatial order was given to plots of land 236 and 237, and the worst, to land 
plot $229 / 2$. Nearly $37 \%$ of plots were placed in the third class of spatial order, with $10 \%$ of plots assigned to the first class. After taking into account the features indicated by local farmers, which do not form part of the spatial order indicators, this distribution changes slightly. The third class of the utilitarian attractiveness now covers almost $40 \%$ of plots, and in the lowest class includes $10 \%$ of plots. A comparison of the two analyses gives us the opportunity to examine how spatial order affects the usability (utilitarian attractiveness) of plots, and how it matches the preferences of farmers when it comes to the functionality of using the plot.

The contemporary condition of spatial order in rural areas and the dynamic socioeconomic development forces us to improve the spatial order. Due to the diverse nature of various spatial elements present in rural areas, ensuring spatial order in these areas is difficult. The application of the developed indicators gives us the opportunity to specify which of the elements of the space being assessed have a negative impact on the overall spatial order and the condition of spatial development. Indication of elements, which damage spatial order and introduce chaos, allows for quick improvement of the spatial structure of managing and using rural areas.

This research was financed by Ministry of Science and Higher Education, under grant number 28.610.015-300.

\section{References}

Balon J. 2011. Wyróżnienie atrybutów atrakcyjności krajobrazu jako metoda oceny obszarów cennych przyrodniczo. Wydawnictwo Politechniki Krakowskiej, Kraków.

Bański J. 2008. Ład przestrzenny obszarów wiejskich ze szczególnym uwzględnieniem oddziaływania gospodarki rolnej. Wydawnictwo Instytutu Geografii i Przestrzennego Zagospodarowania, Warszawa.

Borsa M. 2007. Podstawy urbanistyki i planowania przestrzennego. Materiały dla studentów Szkoły Głównej Handlowej w Warszawie.

Bourne L. 2001. The urban sprawl debate. Myths, realities and hidden agenda. Plan Canada. $41(4), 26-28$.

Cymerman R. 2011. Podstawy planowania przestrzennego i projektowania urbanistycznego. Wydawnictwo UWM, Olsztyn.

Cymerman R., Podciborski T. 2004. Propozycja metody oceny ładu przestrzennego przy analizie stanu zagospodarowania obszarów wiejskich. Acta Sci. Pol., ser. Administratio Locorum, 3, 1.

Dembowska Z. 1978. Planowanie przestrzenne w ujęciu systemowym. PWN, Warszawa.

Domański R. 1989. Podstawy planowania przestrzennego. PWN, Warszawa.

Filion E. 2000. Balancing concentration and dispersion? Public policy and urban structure in Toronto. Environment and Planning, C, 18, 163-189.

Filion P. 2003. Towards smart growth. The difficult implementation of alternatives to urban dispersion. Canadian Journal of Urban Research, 12, 1, Summer, 48-60.

Gniadek J. 2012. Wpływ rozłogów pól ornych i przestrzennych cech gospodarstw na koszty uprawowe we wsi Filipowice [Influence of the land configuration of arable lands and farms spatial features on cultivation costs in Filipowice village]. Infrastruktura i Ekologia Terenów Wiejskich, 1(III), 231-241. 
Goodland R. 1995. The Concept of Environmental Sustainability. Annual Review of Ecology and Systematics.

Gutry-Korycka M. (ed.). 2005. Urban sprawl. Warsaw agglomeration, case study. Warsaw University Press, Warszawa.

Harasimowicz S., Janus J., Ostrągowska B. 2009. Optymalizacja wiejskiego układu gruntowego wykorzystująca podział kompleksów projektowania działek na paski elementarne. Przegląd Geodezyjny, 5, 3-12.

Hełdak M. 2010. Rozwój przestrzenny zabudowy w strefie dużych miast [Building development in suburban areas]. Acta Sci. Pol., ser. Administratio Locorum, 9 (1).

Jałowiecki B. 2003. Ład społeczny, ład przestrzenny. Biuletyn KPZK, 205, 45-54.

Lisowski A. 2005. Janusowe oblicze suburbanizacji. [W:] Współczesne problemy urbanizacji i ich skutki. XIX Konwersatorium Wiedzy o Mieście, red. I. Jażdżewska, Uniwersytet Łódzki, Łódź, 91-100.

Litwińska E. 2008. Zjawisko urban sprawl - jeden z wymiarów współczesnych procesów urbanizacji. [W:] Współczesne kierunki i wymiary procesów urbanizacji, red. J. Słodczyk, M. Śmigielska. Wydawnictwo Uniwersytetu Opolskiego, Opole, 37-48.

Malisz B. 1984. Podstawy gospodarki i polityki przestrzennej. Ossolineum, Wrocław.

Parysek J. 2006. Wprowadzenie do gospodarki przestrzennej. Wybrane aspekty praktyczne. Wydawnictwo UAM, Poznań.

Parysek J. 2008a. Urbanizacja i niektóre współczesne idee, koncepcje i modele planowania rozwoju miast. [W:] Współczesne kierunki i wymiary procesów urbanizacji, red. J. Słodczyk, M. Śmigielska. Uniwersytet Opolski, Opole, 11-26.

Parysek J. 2008b. Suburbanizacja i reurbanizacja: dwa bieguny polskiej urbanizacji. [W:] Region społeczno-ekonomiczny i rozwój regionalny, red. J. Parysek, T. Stryjakiewicz. Bogucki Wydawnictwo Naukowe, Poznań, 261-286.

Płaza M., Ruszczycka K., Mazur A. 2014. Przekształcenia układów ruralistycznych na przykładzie żuławskiej wsi Adamowo [Transformation of Rural Complexes on the Basis of Village Adamowo in the Area of Żuławy (Northern Poland)]. Episteme, 22, II, 121-127.

Podciborski T., Kil J. 2011. Ład przestrzenny obszarów peryferyjnych w aspekcie podziałów nieruchomości niezurbanizowanych. Barometr Regionalny, 3(25), 79-84.

Podciborski T., Trystuła A. 2010. Wykorzystanie systemu GIS do oceny stanu ładu przestrzennego obszarów wiejskich. Infrastruktura i Ekologia Terenów Wiejskich, PAN, Oddział w Krakowie, 13, 5-18.

Radziszewska W., Jaroszewicz J. 2012. Ocena istniejącej sieci dróg transportu rolnego na obszarze wsi poddanej pracom scaleniowym [The assessment of the existing of agricultural roads in a village under the land consolidation process]. Acta Sci. Pol., ser. Geodesia et Descriptio Terrarum, 11, 3, 17-34.

Sadura P. 2017. Wieś w Polsce 2017 - diagnoza i prognoza. Fundacja Wspomagania Wsi.

Stanny M., Czarnecki A. 2011. Zrównoważony rozwój obszarów wiejskich Zielonych Płuc Polski. Próba analizy empirycznej. IRWiR, PAN.

Sydorovych O., Wossink A. 2008. The Meaning of Agricultural Sustainability: Evidence from a Conjoint Choice Survey. Agricultural Systems.

Śleszyński P. 2013. Propozycja kompleksowej koncepcji wskaźników zagospodarowania i ładu przestrzennego. IGiPZ, Warszawa.

Śleszyński P. 2015. Mapa krajobrazu kulturowego Polski w koncepcji przestrzennego zagospodarowania kraju 2030. Prace Komisji Krajobrazu Kulturowego, 27, 45-62.

Wdowicka M., Mierzejewska L. 2012. Chaos w zagospodarowaniu przestrzennym stref podmiejskich jako efekt braku zintegrowanego systemu planowania (na przykładzie strefy podmiejskiej Poznania). Instytut Rozwoju Miast. 
Woch F. 2012. Ocena efektywności scaleń gruntów realizowanych w Polsce w ramach wspólnej polityki rolnej Unii Europejskiej. Infrastruktura i Ekologia Terenów Wiejskich, 2 (III), 101-112.

Wysocka E., Witkowska J. 2004. Zagospodarowanie przestrzenne. IGPiK, Warszawa.

Zarzycki J. 2011. Sposób użytkowania gruntów w przeszłości (XIX i koniec XX w.) jako czynnik kształtujący aktualny stan roślinności łąkowej w paśmie Radziejowej (Beskid Sądecki). Roczniki Bieszczadzkie, 19, 33-42.

Żmija D. 2014. Zrównoważony rozwój rolnictwa i obszarów wiejskich w Polsce, Uniwersytet Ekonomiczny w Krakowie.

Żylicz T. 2004. Ekonomia środowiska i zasobów naturalnych. PWE, Warszawa.

\section{Appendix 1}

Plot assessment criteria according to individual indicators

Table 1. The shape of the plot's boundary (1)

\begin{tabular}{|c|c|c|c|c|c|}
\hline \multicolumn{6}{|c|}{ Table for the assessment of plot boundary shape } \\
\hline \multirow{2}{*}{$\begin{array}{l}\text { Shape } \\
\text { of the plot }\end{array}$} & \multicolumn{4}{|c|}{ Size of the plot area [ha] } & \multirow{2}{*}{$\begin{array}{l}\text { Number } \\
\text { of points }\end{array}$} \\
\hline & $0-1$ & $1-2$ & $2-5$ & $>5$ & \\
\hline Regular & \multicolumn{2}{|c|}{ regular rectangle } & $\begin{array}{l}\text { two pairs of sides } \\
\text { are parallel }\end{array}$ & $\begin{array}{l}\text { the pair of longer } \\
\text { sides is parallel }\end{array}$ & 3 \\
\hline $\begin{array}{l}\text { Fairly } \\
\text { regular }\end{array}$ & $\begin{array}{l}\text { two longer } \\
\text { sides are } \\
\text { parallel }\end{array}$ & $\begin{array}{l}\text { one bend/break } \\
\text { in the longer } \\
\text { boundaries is } \\
\text { permitted, two } \\
\text { longer boundaries } \\
\text { are parallel }\end{array}$ & $\begin{array}{l}\text { two bends/breaks } \\
\text { in the longer } \\
\text { boundaries are } \\
\text { permitted, two } \\
\text { longer sides are } \\
\text { parallel }\end{array}$ & $\begin{array}{l}\text { more than three } \\
\text { bends/breaks in the } \\
\text { longer boundaries } \\
\text { are permitted, two } \\
\text { longer sides are } \\
\text { parallel }\end{array}$ & 1.5 \\
\hline Irregular & \multicolumn{4}{|c|}{ other } & 0 \\
\hline
\end{tabular}

Source: Authors' own study based on Cymerman [2011]

Table 2. Fitting the plot into spatial invariants (2)

\begin{tabular}{|c|c|c|}
\hline \multicolumn{3}{|c|}{ Table for the assessment of fitting the plot into spatial invariants } \\
\hline Border fit & $\begin{array}{c}\text { Percentage share of natural boundaries } \\
\text { in the total length of the boundaries }\end{array}$ & $\begin{array}{c}\text { Number } \\
\text { of points }\end{array}$ \\
\hline I - very high & $\mathrm{U}>75 \%$ & 3 \\
\hline II - high & $50 \%<\mathrm{U} \leq 75 \%$ & 2 \\
\hline III - medium & $25 \%<\mathrm{U} \leq 50 \%$ & 1 \\
\hline IV - low & $0 \% \leq \mathrm{U} \leq 25 \%$ & 0 \\
\hline $\begin{array}{l}\text { Where: } \mathrm{U}-\text { percentage share of plot boundaries determined by spatial invariants (such as forest, } \\
\text { river, hard-surface road) to the total length of the plot's boundary }\end{array}$
\end{tabular}

Source: Authors' own study based on Cymerman [2011] 
Table 3. Straightness of artificial (cadastral) boundaries separating the neighbouring plots (3)

Table for the assessment of straightness of the artificial (cadastral) boundaries of the plot

\begin{tabular}{|c|c|}
\hline Number of bends/breaks of the plot's boundaries & Number of points \\
\hline 4 & 3 \\
\hline 3 or 5 & 2 \\
\hline $6-10$ & 1 \\
\hline$>10$ & 0 \\
\hline
\end{tabular}

Source: Authors' own study based on Cymerman [2011]

Table 4. Orientation of the plot versus the cardinal directions (4)

Table for the assessment of the plot's orientation versus the cardinal directions

\begin{tabular}{|l|c|}
\hline \multicolumn{1}{|c|}{ Description of the orientation/direction of the boundary } & Number of points \\
\hline North-South $\left( \pm 22.5^{\circ}\right)$ & 3 \\
\hline North-East, South-West $\left( \pm 22.5^{\circ}\right)$ & 2 \\
\hline East-West $\left( \pm 22.5^{\circ}\right)$ & 1 \\
\hline Impossible to determine the orientation & 0 \\
\hline
\end{tabular}

The score takes into account the orientation of the longer sides/boundaries of the plot, directional tolerance $+/-22.5^{\circ}$

Source: Authors' own study based on Cymerman [2011]

Table 5. Transportation accessibility of the plot (5)

\begin{tabular}{|l|c|c|}
\hline \multicolumn{2}{|c|}{ Table for the assessment of transportation accessibility of the plot } \\
\hline \multicolumn{1}{|c|}{ Level of transportation accessibility } & Length of roads [per 1 ha] & Number of points \\
\hline Very low & $0 \mathrm{~m} \leq \mathrm{U}<10 \mathrm{~m}$ & 1 \\
\hline Low & $10 \mathrm{~m} \leq \mathrm{U}<20 \mathrm{~m}$ & 2 \\
\hline Insufficient on average & $20 \mathrm{~m} \leq \mathrm{U}<30 \mathrm{~m}$ & 3 \\
\hline Optimum & $30 \mathrm{~m} \leq \mathrm{U}<40 \mathrm{~m}$ & 2 \\
\hline Excessive on average & $40 \mathrm{~m} \leq \mathrm{U}<50 \mathrm{~m}$ & 1 \\
\hline High & $50 \mathrm{~m} \leq \mathrm{U}<60 \mathrm{~m}$ & 0 \\
\hline Much too high & $60 \mathrm{~m} \geq \mathrm{U}$ & \\
\hline Where: $\mathrm{U}$ - length of accessible roads in metres & & \\
\hline
\end{tabular}

Source: Authors' own study based on Cymerman [2011] 
Table 6. Inner linear disharmony of the plot (6)

\begin{tabular}{|l|c|}
\hline \multicolumn{2}{|c|}{ Table for the assessment of inner linear disharmony of the plot } \\
\hline \multicolumn{1}{|c|}{ Percentage share } & Number of points \\
\hline $0.00 \% \leq \mathrm{U}<0.10 \%$ & 3 \\
\hline $0.10 \% \leq \mathrm{U}<1.00 \%$ & 2 \\
\hline $1.00 \% \leq \mathrm{U}<2.20 \%$ & 1 \\
\hline $\mathrm{U} \geq 2.20 \%$ & 0 \\
\hline
\end{tabular}

Source: Authors' own study based on Cymerman [2011]

Table 7. Spatial harmony of land ownership (7)

\begin{tabular}{|l|c|}
\hline \multicolumn{2}{|c|}{ Table for the assessment of spatial harmony of plot's ownership } \\
\hline \multicolumn{1}{|c|}{ Percentage share of boundaries with similar plots } & Number of points \\
\hline $\mathrm{U}>75 \%$ & 3 \\
\hline $50 \%<\mathrm{U} \leq 75 \%$ & 2 \\
\hline $25 \%<\mathrm{U} \leq 50 \%$ & 1 \\
\hline $0 \% \leq \mathrm{U} \leq 25 \%$ & 0 \\
\hline Where: $\mathrm{U}-$ percentage share of plot boundaries with similar plots \\
\hline
\end{tabular}

Source: Authors' own study based on Cymerman [2011]

Table 8. Land ownership homogeneity of the interior of the plot (9)

\begin{tabular}{|c|c|c|c|c|c|c|c|c|c|c|c|c|c|c|c|c|c|c|c|c|c|}
\hline \multirow{3}{*}{$\begin{array}{c}\text { Number } \\
\text { of ecological } \\
\text { contours }\end{array}$} & \multicolumn{21}{|c|}{ Number of points depending on the plot size } \\
\hline & \multicolumn{21}{|c|}{ Plot size ranges [ha] } \\
\hline & $\begin{array}{l}\text { ra } \\
\text { 1} \\
0\end{array}$ & 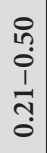 & $\frac{8}{8}$ & 우 & $\begin{array}{c}8 \\
\stackrel{8}{i} \\
1 \\
\\
\end{array}$ & $\begin{array}{l}0 \\
i \\
i \\
1 \\
0 \\
i \\
i\end{array}$ & $\begin{array}{l}8 \\
0 \\
1 \\
1 \\
\dot{n} \\
\dot{1}\end{array}$ & $\begin{array}{l}\text { in } \\
\text { ñ } \\
1 \\
0 \\
\text { n் }\end{array}$ & $\begin{array}{l}8 \\
\stackrel{+}{+} \\
\frac{1}{n} \\
\text { n் }\end{array}$ & 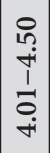 & $\begin{array}{c}8 \\
\dot{0} \\
1 \\
\frac{1}{n} \\
\dot{+1}\end{array}$ & $\begin{array}{c}0 \\
1 \\
10 \\
1 \\
0 \\
\text { in }\end{array}$ & $\begin{array}{c}8 \\
0 \\
0 \\
1 \\
1 n \\
\text { in }\end{array}$ & $\begin{array}{l}8 \\
0 \\
1 \\
0 \\
0 \\
0\end{array}$ & $\begin{array}{l}8 \\
0 \\
\infty \\
1 \\
0 \\
1 \\
1\end{array}$ & $\begin{array}{l}0 \\
1 \\
1 \\
0 \\
\infty \\
\infty\end{array}$ & $\begin{array}{l}10 \\
1 \\
0\end{array}$ & $\begin{array}{l}\text { ㄱ } \\
1 \\
\text { L }\end{array}$ & 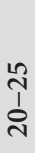 & $\begin{array}{l}\hat{1} \\
\text { Î } \\
\text { nิ }\end{array}$ & $\stackrel{\stackrel{1}{m}}{\wedge}$ \\
\hline 1 & 3 & 3 & 3 & 3 & 3 & 3 & 3 & 3 & 3 & 3 & 3 & 3 & 3 & 3 & 3 & 3 & 3 & 3 & 3 & 3 & 3 \\
\hline 2 & 0 & 0.6 & 1.2 & 1.8 & 1.8 & 2.4 & 2.4 & 2.4 & 2.4 & 3 & 3 & 3 & 3 & 3 & 3 & 3 & 3 & 3 & 3 & 3 & 3 \\
\hline 3 & 0 & 0 & 0.6 & 1.2 & 1.8 & 1.8 & 1.8 & 2.4 & 2.4 & 2.4 & 2.4 & 2.4 & 2.4 & 3 & 3 & 3 & 3 & 3 & 3 & 3 & 3 \\
\hline 4 & 0 & 0 & 0.6 & 1.2 & 1.2 & 1.8 & 1.8 & 1.8 & 1.8 & 2.4 & 2.4 & 2.4 & 2.4 & 2.4 & 2.4 & 3 & 3 & 3 & 3 & 3 & 3 \\
\hline 5 & 0 & 0 & 0.6 & 0.6 & 1.2 & 1.2 & 1.8 & 1.8 & 1.8 & 1.8 & 1.8 & 2.4 & 2.4 & 2.4 & 2.4 & 2.4 & 3 & 3 & 3 & 3 & 3 \\
\hline
\end{tabular}




\begin{tabular}{|c|l|l|l|l|l|l|l|l|l|l|l|l|l|l|l|l|l|l|l|l|l|}
\hline 6 & 0 & 0 & 0.6 & 0.6 & 1.2 & 1.2 & 1.2 & 1.8 & 1.8 & 1.8 & 1.8 & 1.8 & 1.8 & 2.4 & 2.4 & 2.4 & 3 & 3 & 3 & 3 & 3 \\
\hline 7 & 0 & 0 & 0.6 & 0.6 & 0.6 & 1.2 & 1.2 & 1.2 & 1.8 & 1.8 & 1.8 & 1.8 & 1.8 & 1.8 & 2.4 & 2.4 & 3 & 3 & 3 & 3 & 3 \\
\hline 8 & 0 & 0 & 0 & 0.6 & 0.6 & 0.6 & 1.2 & 1.2 & 1.2 & 1.8 & 1.8 & 1.8 & 1.8 & 1.8 & 1.8 & 1.8 & 3 & 3 & 3 & 3 & 3 \\
\hline 9 & 0 & 0 & 0 & 0.6 & 0.6 & 0.6 & 0.6 & 1.2 & 1.2 & 1.2 & 1.8 & 1.8 & 1.8 & 1.8 & 1.8 & 1.8 & 2.4 & 3 & 3 & 3 & 3 \\
\hline 10 & 0 & 0 & 0 & 0.6 & 0.6 & 0.6 & 0.6 & 0.6 & 1.2 & 1.2 & 1.2 & 1.8 & 1.8 & 1.8 & 1.8 & 1.8 & 2.4 & 3 & 3 & 3 & 3 \\
\hline 11 & 0 & 0 & 0 & 0.6 & 0.6 & 0.6 & 0.6 & 0.6 & 1.2 & 1.2 & 1.2 & 1.8 & 1.8 & 1.8 & 1.8 & 1.8 & 2.4 & 3 & 3 & 3 & 3 \\
\hline 12 & 0 & 0 & 0 & 0.6 & 0.6 & 0.6 & 0.6 & 0.6 & 1.2 & 1.2 & 1.2 & 1.2 & 1.8 & 1.8 & 1.8 & 1.8 & 2.4 & 2.4 & 3 & 3 & 3 \\
\hline 13 & 0 & 0 & 0 & 0 & 0.6 & 0.6 & 0.6 & 0.6 & 0.6 & 1.2 & 1.2 & 1.2 & 1.2 & 1.8 & 1.8 & 1.8 & 2.4 & 2.4 & 3 & 3 & 3 \\
\hline 14 & 0 & 0 & 0 & 0 & 0.6 & 0.6 & 0.6 & 0.6 & 0.6 & 0.6 & 1.2 & 1.2 & 1.2 & 1.2 & 1.8 & 1.8 & 2.4 & 2.4 & 3 & 3 & 3 \\
\hline 15 & 0 & 0 & 0 & 0 & 0.6 & 0.6 & 0.6 & 0.6 & 0.6 & 0.6 & 1.2 & 1.2 & 1.2 & 1.2 & 1.8 & 1.8 & 2.4 & 2.4 & 2.4 & 3 & 3 \\
\hline 16 & 0 & 0 & 0 & 0 & 0.6 & 0.6 & 0.6 & 0.6 & 0.6 & 0.6 & 0.6 & 1.2 & 1.2 & 1.2 & 1.2 & 1.8 & 1.8 & 2.4 & 2.4 & 3 & 3 \\
\hline 17 & 0 & 0 & 0 & 0 & 0.6 & 0.6 & 0.6 & 0.6 & 0.6 & 0.6 & 0.6 & 1.2 & 1.2 & 1.2 & 1.2 & 1.2 & 1.8 & 2.4 & 2.4 & 3 & 3 \\
\hline 18 & 0 & 0 & 0 & 0 & 0 & 0.6 & 0.6 & 0.6 & 0.6 & 0.6 & 0.6 & 0.6 & 1.2 & 1.2 & 1.2 & 1.2 & 1.8 & 1.8 & 2.4 & 3 & 3 \\
\hline 19 & 0 & 0 & 0 & 0 & 0 & 0.6 & 0.6 & 0.6 & 0.6 & 0.6 & 0.6 & 0.6 & 0.6 & 1.2 & 1.2 & 1.2 & 1.8 & 1.8 & 2.4 & 2.4 & 3 \\
\hline 20 & 0 & 0 & 0 & 0 & 0 & 0.6 & 0.6 & 0.6 & 0.6 & 0.6 & 0.6 & 0.6 & 0.6 & 1.2 & 1.2 & 1.2 & 1.8 & 1.8 & 2.4 & 2.4 & 3 \\
\hline 20 & 0 & 0 & 0 & 0 & 0 & 0.6 & 0.6 & 0.6 & 0.6 & 0.6 & 0.6 & 0.6 & 0.6 & 0.6 & 1.2 & 1.2 & 1.8 & 1.8 & 2.4 & 2.4 & 3 \\
\hline
\end{tabular}

Source: Authors' own study based on Cymerman [2011]

\section{Features taken into account after conducting a survey among the local farmers}

Table 9. Total area size of the plot (11)

\begin{tabular}{|c|c|}
\hline \multicolumn{2}{|c|}{ Table for the assessment of plot size } \\
\hline Plot area [ha] & Number of points \\
\hline $5.01-8.00$ ha & 3 \\
\hline $2.51-5.00$ ha or $>8$ ha & 2.3 \\
\hline $1.31-2.50$ ha & 0.5 \\
\hline $0.3-1.30$ ha & 0 \\
\hline $0-0.29$ ha & 0.8 \\
\hline
\end{tabular}

Source: Authors' own study based on surveys 
Table 10. Distance from the plot to compact built-up area (potential habitat) (10)

\begin{tabular}{|c|c|}
\hline \multicolumn{2}{|c|}{ Table for the assessment of distance to compact built-up area } \\
\hline Distance to compact built-up $[\mathrm{km}]$ & Number of points \\
\hline $0-0.5 \mathrm{~km}$ & 3 \\
\hline $0.51-1.00 \mathrm{~km}$ & 2.3 \\
\hline $1.01-1.50 \mathrm{~km}$ & 1.5 \\
\hline $1.51-2.00 \mathrm{~km}$ & 0.8 \\
\hline$>2.00 \mathrm{~km}$ & 0 \\
\hline
\end{tabular}

Source: Authors' own study based on surveys

Table 11. Quality of land/soil in the plot according to soil quality (bonitation) class (12)

\begin{tabular}{|c|c|}
\hline \multicolumn{2}{|c|}{ Table for the assessment of soil quality in the plot } \\
\hline Dominant soil class in the plot S & Number of points \\
\hline $\mathrm{I}^{-\mathrm{IVa}^{*}}$ & 2 \\
\hline $\mathrm{IVb}$ & 1 \\
\hline $\mathrm{V}$ & 0 \\
\hline $\mathrm{VI}, \mathrm{N}$ & 2 \\
\hline$*$ According to the locally adopted scale, as the maximum class in the area ion question is IVa \\
\hline
\end{tabular}

Source: Authors' own study based on surveys

Mgr inż. Robert Muszyński

Uniwersytet Warmińsko-Mazurski w Olsztynie

Wydział Geodezji, Inżynierii Przestrzennej i Budownictwa

Instytut Geoinformacji i Kartografii

10-728 Olsztyn, ul. Prawocheńskiego 15

e-mail: robert19musz@tlen.pl

Dr hab. inż. Katarzyna Kocur-Bera, prof. UWM

Uniwersytet Warmińsko-Mazurski w Olsztynie

Wydział Geodezji, Inżynierii Przestrzennej i Budownictwa

Instytut Geoinformacji i Kartografii

10-728 Olsztyn, ul. Prawocheńskiego 15/105

e-mail: katarzyna.kocur@uwm.edu.pl

ORCID: 0000-0001-7056-5443 